\title{
Communication Pattern for Attaining Information Regarding Cashless System
}

\author{
Manisha Ohlan and Ella Rani* \\ Department of Extension Education and Communication Management, I.C. College of Home \\ Sciences, CCS Haryana Agricultural University, Hisar, Haryana, India \\ *Corresponding author
}

\section{A B S T R A C T}

\section{Keywords}

Cashless system,

Mass media exposure,

Information source utilization, Internet exposure

Article Info

Accepted:

20 May 2019

Available Online:

10 June 2019
The present study was conducted in Hisar district of Haryana state covering 200 respondents from two localities viz., rural and urban. Results shows majority of respondents had possession of Cable TV, followed by television and newspaper and had high mass media exposure. A recent survey found that 112 million households in India own a television, with 61 percent of those homes having cable or satellite service (National Readership Studies Council, 2006). In China, television exposure grew from 18 million people in 1977 to 1 billion by 1995 (Thomas, 2003). In more recent years, satellite and cable television availability had increased dramatically. Majority of respondents had high utilization of localite sources and low utilization of cosmopolite sources. It was also found that majority of respondents had exposure of PayTm for using cashless system, followed by credit card and internet banking. Brid et al., (2017) identified that PayTm had maximum users, other features lack in somewhat features compared with PayTm, so people preferred to use PayTm than other apps.

\section{Introduction}

Since 9th November 2016, the two highdenomination currencies of our country, the 500 and 1000 rupee notes, lost their monetary worth. When Prime Minister Modi announced about this demonetization in the Prime Time News the previous evening, it took the whole country by surprise. This masterstroke by government to fight the financial issues of the country, like black money hoarding, terror financing, counterfeit currency, parallel economy, etc., was welcomed and praised by many people in the electronic and social media. Cashless economy could be a scenario during which the flow of money inside associate economy is non-existent and ever one is doing transaction through electronic media channels like direct debit, credit and debit cards, and electronic clearing and payment systems like cash Immediate Payments Service (IMPS), National Electronic Funds Transfer (NEFT) and Real Time Gross Settlement (RTGS).

Due to demonetization, more and more people have started understanding the need for utilizing digital payments. There are a lot of 
digital payment methods like mobile wallets, Unified Payment Interface, card payments, net banking, etc. Sharma (2012) described that the need of internet banking in rural areas as Indian economy was highly dominated by rural people. It was important to provide services which traditional banking facilities might not be able to provide with the help of existing banking system. Therefore, there was a need to create alternative service exclusively for the rural poor. Services and facilities provided at the non-rural areas might not be superimposed. Factors like adequate arrangement of ATMs, customer training facility, cost of maintaining bank accounts, transportation etc. were some of the factors that might create problem. Unless and until these facilities were not improved, the banks might not be able to provide the services required in the rural sector.

The World Bank has estimated India's black money in 2010 to be worth about one fifth of the Gross Domestic Product (GDP). In a country where 90 per cent transactions are carried out on cash basis, it was a revolutionary move to transform from cash to cashless transactions. Under this scheme, 250 million bank accounts have been opened in two years.

As per Reserve Bank of India reports, bank branches increased by 5 per cent per year but ATM cards, debit cards and card swiping machines have doubled in four years and online transactions have grown 20 times in six years to 2016. All these data shows a gradual shift towards cashless economy. Demonetization has speed up this transition (Tawade, 2017). Brid et al., (2017) identified that PayTm had maximum users, other features lack in somewhat features compared with PayTm, so people preferred to use PayTm than other apps. Present study was planned to identify constraints in utilization of cashless system.

\section{Materials and Methods}

The study was conducted in Hisar district of Haryana state selected purposively in both rural and urban areas. For rural respondents, from Hisar district two villages; Ludas and Shahpur were selected randomly. For urban respondents, two localities; Sector-14 and Sector-15 from Hisar city were selected randomly to assess constraints about cash less system of the respondents. A total of 200 respondents which comprised of 100 rural respondents ( 25 females, 25 males) from each village and 100 urban respondents (25 females, 25 males) from each locality having at least higher secondary education were selected purposively. A well-structured interview schedule was used for communication profile of the respondents for attaining information regarding cash less system as a tool for data collection. Data were collected personally by the researcher.

\section{Results and Discussion}

Communication profile of the respondents for attaining information regarding cash less system

The communication pattern of the respondents was analyzed through three parameters viz. mass media exposure, information source utilization and internet exposure.

\section{Mass media exposure}

The data presented in Table 1 and 2 points to the fact that 93 per cent of the respondents in rural area had possession of mass media as Cable TV, which was followed by television (74\%), newspaper (66\%), books $(57 \%)$, films $(48 \%)$, radio $(34 \%)$, magazine $(29 \%)$, leaflets/pamphlets (21\%), newsletters (15\%), handouts (16\%) and slides (12\%). Whereas, in urban area, majority of the respondents 
(97\%) had mass media as newspaper, followed by Cable TV (94\%), television and newsletters (84\% each), books (63\%), magazine (57\%), radio (49\%), leaflets/pamphlets and films (37\%), handouts $(30 \%)$ and slides $(23 \%)$ respectively.

A recent survey found that 112 million households in India own a television, with 61 percent of those homes having cable or satellite service (National Readership Studies Council, 2006). In China, television exposure grew from 18 million people in 1977 to 1 billion by 1995 (Thomas, 2003). In more recent years, satellite and cable television availability had increased dramatically.

The Table further depicts that, in rural area, 36 per cent of the respondents had medium level mass media exposure, which was followed by low exposure (35\%) and high exposure $(29 \%)$. While, in urban area, more than half of the respondents $(57 \%)$ had high mass media exposure, which was followed by medium exposure $(28 \%)$ and low exposure $(15 \%)$. Thus, in case of pooled weighted mean, nearly half of the respondents (43\%) had high mass media exposure, which was followed by medium exposure $(32 \%)$ and low exposure $(25 \%)$.

Thus, it can be concluded that majority of respondents had possession of Cable TV, followed by television and newspaper and had high mass media exposure (Fig. 1).

\section{Information source utilization}

Regarding utilization of localite sources, it can be observed from Table 3 that in rural area, more than half of the respondents $(57 \%)$ had high utilization of localite sources, which was followed by medium (32\%) and low utilization $(11 \%)$. Whereas, in urban area, nearly half of the respondents $(45 \%)$ had high utilization of localite sources, which was followed by low (28\%) and medium (27\%). Thus, in case of pooled sample mean, it was found that half of the respondents $(51 \%)$ had high utilization of localite sources, which was followed by medium (29.5\%) and low (19.5\%) (Fig. 2).

Table.1 Possession of mass media by respondents for attaining information Regarding cash less system

\begin{tabular}{|c|l|c|c|c|}
\hline Sr. No. & Mass media & $\begin{array}{c}\text { Rural } \\
(\mathbf{\%}) \\
(\mathbf{n = 1 0 0})\end{array}$ & $\begin{array}{c}\text { Urban } \\
(\mathbf{\%}) \\
(\mathbf{n = 1 0 0})\end{array}$ & $\begin{array}{c}\text { Total } \\
\mathbf{f}(\boldsymbol{\%}) \\
(\mathbf{N = 2 0 0})\end{array}$ \\
\hline $\mathbf{1 .}$ & Radio & 34.00 & 49.00 & $83(41.50)$ \\
\hline $\mathbf{2 .}$ & Television & 74.00 & 84.00 & $158(79.00)$ \\
\hline $\mathbf{3 .}$ & Newspaper & 66.00 & 97.00 & $163(81.50)$ \\
\hline $\mathbf{4 .}$ & Magazine & 29.00 & 57.00 & $86(43.00)$ \\
\hline $\mathbf{5 .}$ & Cable T.V & 93.00 & 94.00 & $187(93.50)$ \\
\hline $\mathbf{6 .}$ & Books & 57.00 & 63.00 & $120(60.00)$ \\
\hline $\mathbf{7 .}$ & Newsletters & 15.00 & 84.00 & $99(49.50)$ \\
\hline $\mathbf{8 .}$ & Leaflets/ Pamphlets & 21.00 & 37.00 & $58(29.00)$ \\
\hline $\mathbf{9 .}$ & Handouts & 16.00 & 30.00 & $46(23.00)$ \\
\hline $\mathbf{1 0 .}$ & Slides & 12.00 & 23.00 & $35(17.50)$ \\
\hline $\mathbf{1 1 .}$ & Films & 48.00 & 37.00 & $85(42.50)$ \\
\hline
\end{tabular}

Figures in parentheses indicate percentage 
Table.2 Mass media exposure of respondents for attaining information Regarding cash less system

\begin{tabular}{|c|l|c|c|c|}
\hline $\begin{array}{c}\text { Sr. } \\
\text { No. }\end{array}$ & Mass media & $\begin{array}{c}\text { Rural } \\
(\mathbf{\%}) \\
(\mathbf{n = 1 0 0})\end{array}$ & $\begin{array}{c}\text { Urban } \\
(\mathbf{\%}) \\
(\mathbf{n = 1 0 0 )}\end{array}$ & $\begin{array}{c}\text { Total } \\
\mathbf{f}(\mathbf{\%}) \\
(\mathbf{N}=\mathbf{2 0 0})\end{array}$ \\
\hline i. & Low & 35.00 & 15.00 & $50(25.00)$ \\
\hline ii. & Medium & 36.00 & 28.00 & $64(32.00)$ \\
\hline iii. & High & 29.00 & 57.00 & $86(43.00)$ \\
\hline
\end{tabular}

Figures in parentheses indicate percentage

Table.3 Information source utilization for cash less system by respondents

\begin{tabular}{|c|l|c|c|c|}
\hline Sr. No. & Information source utilization & $\begin{array}{c}\text { Rural } \\
(\mathbf{\%}) \\
(\mathbf{n = 1 0 0})\end{array}$ & $\begin{array}{c}\text { Urban } \\
(\mathbf{\%}) \\
(\mathbf{n = 1 0 0})\end{array}$ & $\begin{array}{c}\text { Total } \\
\mathbf{f}(\mathbf{\%}) \\
(\mathbf{N}=\mathbf{2 0 0})\end{array}$ \\
\hline $\mathbf{( a )}$ & Localite Sources & 11 & 28 & $39(19.50)$ \\
\hline & Low & 32 & 27 & $59(29.50)$ \\
\hline & Medium & 57 & 45 & $102(51.00)$ \\
\hline & High & 69 & 63 & $132(66.00)$ \\
\hline (b) & Cosmopolite sources & 24 & 28 & $52(26.00)$ \\
\hline & Low & 07 & 09 & $16(08.00)$ \\
\hline & Medium & \multicolumn{3}{|l}{} \\
\hline & High &
\end{tabular}

Figures in parentheses indicate percentage

Table.4 Internet exposure of digital methods for using cash less system by respondents

\begin{tabular}{|c|c|c|c|c|c|c|c|c|c|c|c|c|c|}
\hline \multirow{2}{*}{$\begin{array}{l}\text { Sr. } \\
\text { No. }\end{array}$} & \multirow[t]{2}{*}{ Attributes } & \multicolumn{5}{|c|}{ Rural (n=100) } & \multicolumn{5}{|c|}{ Urban $(n=100)$} & \multicolumn{2}{|c|}{ Total $(\mathrm{N}=200)$} \\
\hline & & $\begin{array}{l}\text { High } \\
\text { (3) }\end{array}$ & $\begin{array}{l}\text { Moderate } \\
\text { (2) }\end{array}$ & $\begin{array}{c}\text { Low } \\
\text { (1) }\end{array}$ & $\begin{array}{l}\text { Weighted } \\
\text { Mean } \\
\text { Score }\end{array}$ & Rank & $\begin{array}{l}\text { High } \\
\text { (3) }\end{array}$ & $\begin{array}{l}\text { Moderate } \\
\text { (2) }\end{array}$ & $\begin{array}{l}\text { Low } \\
(1)\end{array}$ & $\begin{array}{c}\text { Weighted } \\
\text { Mean } \\
\text { Score }\end{array}$ & Rank & $\begin{array}{l}\text { Weighted } \\
\text { Mean } \\
\text { Score }\end{array}$ & Rank \\
\hline 1. & Pay TM & 32 & 33 & 35 & 1.97 & I & 43 & 30 & 27 & 2.16 & I & 2.065 & I \\
\hline 2. & PayPal & 04 & 12 & 84 & 1.20 & $\mathrm{X}$ & 03 & 16 & 81 & 1.22 & XII & 1.210 & XI \\
\hline 3. & MobiKwik & 05 & 17 & 78 & 1.27 & IX & 10 & 15 & 75 & 1.35 & $\mathrm{X}$ & 1.310 & IX \\
\hline 4. & BHIM & 09 & 18 & 73 & 1.36 & VII & 24 & 24 & 52 & 1.72 & V & 1.540 & VI \\
\hline 5. & Internet Banking & 30 & 26 & 44 & 1.86 & II & 44 & 34 & 22 & 2.22 & III & 2.040 & III \\
\hline 6. & Credit Card & 25 & 30 & 45 & 1.80 & IV & 44 & 16 & 40 & 2.04 & IV & 1.920 & IV \\
\hline 7. & Debit Card & 24 & 35 & 41 & 1.83 & III & 60 & 20 & 20 & 2.40 & II & 2.115 & II \\
\hline 8. & Cheque & 16 & 39 & 45 & 1.71 & V & 13 & 41 & 46 & 1.67 & VI & 1.690 & $\mathrm{~V}$ \\
\hline 9. & Demand Draft & 10 & 25 & 65 & 1.45 & VI & 08 & 19 & 73 & 1.35 & $\mathrm{X}$ & 1.400 & VIII \\
\hline 10. & $\begin{array}{l}\text { National Electronic Funds Transfer } \\
\text { (NEFT) }\end{array}$ & 00 & 10 & 90 & 1.10 & XI & 04 & 17 & 79 & 1.25 & XI & 1.175 & $\mathrm{XV}$ \\
\hline 11. & E-Wallet & 00 & 04 & 96 & 1.04 & XIV & 08 & 20 & 72 & 1.36 & IX & 1.200 & XIV \\
\hline 12. & Real Time Gross Settlement (RTGS) & 00 & 02 & 98 & 1.02 & XVI & 03 & 12 & 85 & 1.18 & XIII & 1.100 & XVI \\
\hline 13. & Mobile Wallet & 00 & 08 & 92 & 1.08 & XII & 18 & 17 & 65 & 1.53 & VII & 1.305 & $\mathrm{X}$ \\
\hline 14. & Unified Payments Interface (UPI) & 02 & 04 & 94 & 1.08 & XII & 17 & 19 & 64 & 1.53 & VII & 1.305 & $\mathrm{X}$ \\
\hline 15. & Gift Card & 03 & 02 & 95 & 1.08 & XII & 04 & 09 & 87 & 1.17 & XIV & 1.125 & XIII \\
\hline 16. & $\begin{array}{l}\text { Aadhar Enabled Payment System } \\
\text { (AEPS) }\end{array}$ & 01 & 01 & 98 & 1.03 & $\mathrm{XV}$ & 09 & 23 & 68 & 1.41 & VIII & 1.220 & XII \\
\hline 17. & Immediate Payment Service (IMPS) & 00 & 05 & 95 & 1.05 & XIII & 04 & 10 & 86 & 1.18 & XIII & 1.115 & XVI \\
\hline 18. & SBI Buddy & 06 & 17 & 77 & 1.29 & VIII & 24 & 19 & 57 & 1.67 & VI & 1.480 & VII \\
\hline
\end{tabular}
(Low: 1.00-1.66
Medium: 1.67-2.32
High: 2.33-3.00) 
Fig.1 Mass media exposure of respondents for attaining information regarding cash less system

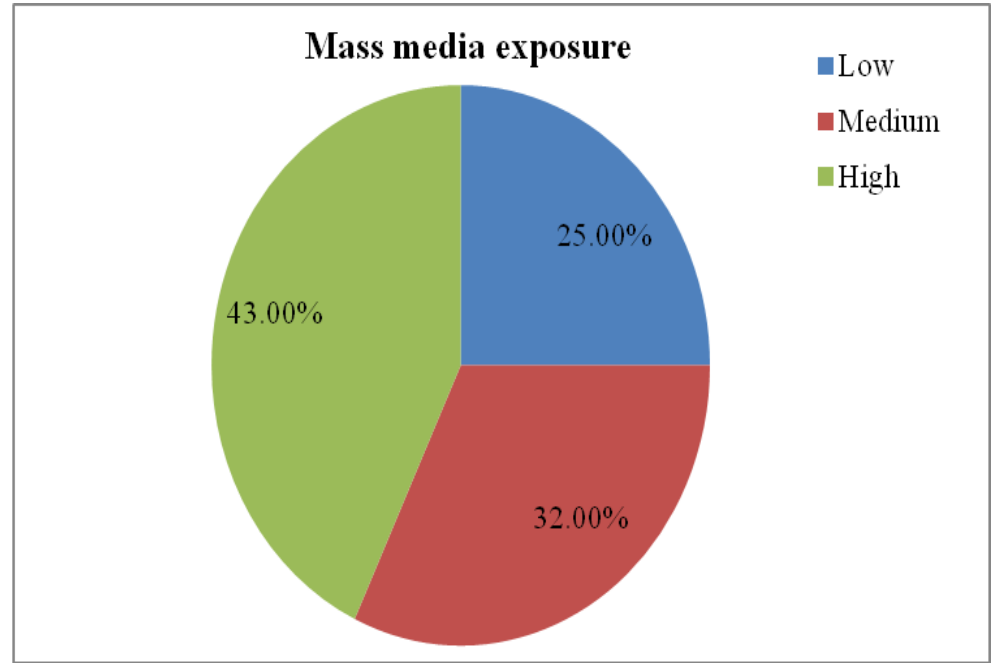

Fig.2 Information source utilization for cash less system by respondent
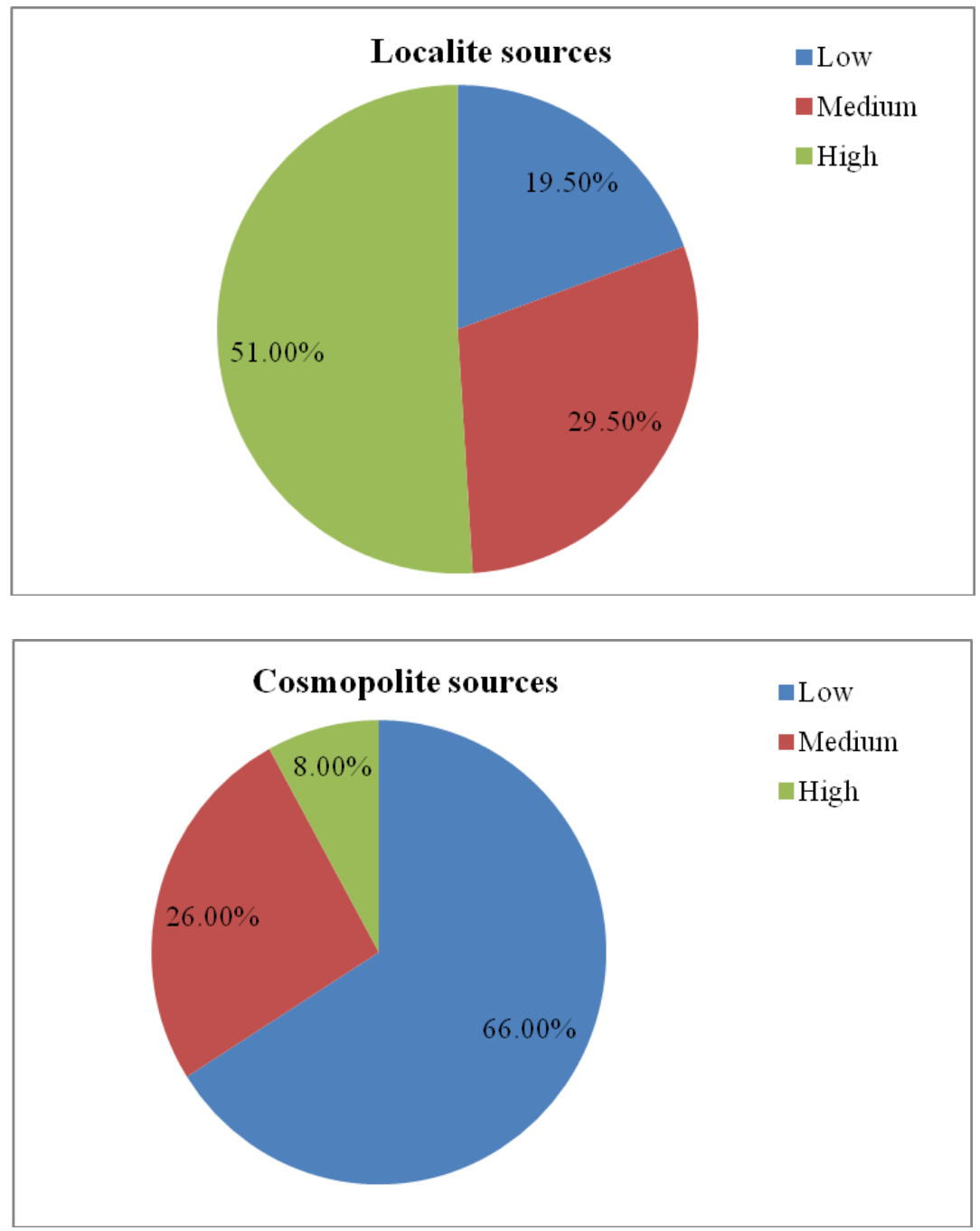
Further, regarding utilization of cosmopolite sources, it can be observed in Table 4 that in rural area, majority of respondents $(69 \%)$ had low utilization, which was followed by medium (24\%) and high (7\%). While, in urban area, 63 per cent of the respondents had low utilization of cosmopolite sources, which was followed by medium (28\%) and high (9\%). Thus, similar trend was followed in case of pooled sample mean.

Thus, it can be concluded that majority of respondents had high utilization of localite sources and low utilization of cosmopolite sources.

\section{Internet exposure of digital methods for using cash less system by respondents}

Majority of respondents in rural area had exposure of PayTm which was given first rank, followed by internet banking (II ${ }^{\text {nd }}$ rank), debit card (III ${ }^{\text {rd }}$ card), credit card (IV ${ }^{\text {th }}$ rank), cheque $\left(\mathrm{V}^{\text {th }}\right.$ rank), demand draft ( $\mathrm{VI}^{\text {th }}$ rank), BHIM app (VII ${ }^{\text {th }}$ rank), SBI buddy (VIII ${ }^{\text {th }}$ rank), MobiKwik (IX ${ }^{\text {th }}$ rank), PayPal $\left(\mathrm{X}^{\text {th }}\right.$ rank), National Electronic Funds Transfer (XI ${ }^{\text {th }}$ rank), mobile wallets, Unified Payments Interface and Gift card (XII ${ }^{\text {th }}$ rank), Immediate Payment Service (XIII ${ }^{\text {th }}$ rank), ewallet $\left(\mathrm{XIV}^{\text {th }}\right.$ rank), Aadhar Enabled Payment System ( $\mathrm{XV}^{\text {th }}$ rank) and Real Time Gross Settlement System $\left(\mathrm{XVI}^{\text {th }}\right.$ rank) respectively.

Whereas, in urban area, majority of respondents had exposure of PayTm which was given first rank, followed by debit card (II ${ }^{\text {nd }}$ rank), internet banking ( $\mathrm{III}^{\text {rd }}$ card), credit card (IV ${ }^{\text {th }}$ rank), BHIM app ( $\mathrm{V}^{\text {th }}$ rank), cheque (VI ${ }^{\text {th }}$ rank), ), mobile wallets and Unified Payments Interface (VII ${ }^{\text {th }}$ rank), Aadhar Enabled Payment System (VIII ${ }^{\text {th }}$ rank), ewallet (IX ${ }^{\text {th }}$ rank), MobiKwik and demand draft $\left(X^{\text {th }}\right.$ rank each) respectively, National Electronic Funds Transfer ( $\mathrm{XI}^{\text {th }}$ rank), PayPal (XII $^{\text {th }}$ rank), Real Time Gross Settlement
System and Immediate Payment Service (XIII ${ }^{\text {th }}$ rank each) and Gift card $\left(\mathrm{XIV}^{\text {th }}\right.$ rank) respectively.

Thus, in case of pooled weighted mean, it was found that majority of respondents had exposure of PayTm which was given first rank, followed by debit card (II ${ }^{\text {nd }}$ rank), internet banking (III ${ }^{\text {rd }}$ rank), credit card (IV ${ }^{\text {th }}$ rank), cheque $\left(\mathrm{V}^{\text {th }}\right.$ rank), BHIM app $\left(\mathrm{VI}^{\text {th }}\right.$ rank), SBI buddy (VII ${ }^{\text {th }}$ rank), demand draft (VIII ${ }^{\text {th }}$ rank), MobiKwik (IX ${ }^{\text {th }}$ rank), mobile wallet and Unified Payments Interface $\left(X^{\text {th }}\right.$ rank), PayPal ( $\mathrm{XI}^{\text {th }}$ rank), Aadhar Enabled Payment System (XII ${ }^{\text {th }}$ rank), Gift card (XIII ${ }^{\text {th }}$ rank), e-wallet $\left(\mathrm{XIV}^{\text {th }}\right.$ rank), National Electronic Funds Transfer $\left(\mathrm{XV}^{\text {th }}\right.$ rank), Real Time Gross Settlement System and Immediate Payment Payment Service $\left(\mathrm{XVI}^{\text {th }}\right.$ rank each) respectively. The results of the study are in aggrement with the study of Brid et al., (2017) identified that PayTm had maximum users, other features lack in somewhat features compared with PayTm, so people preferred to use PayTm than other apps.

It may be concluded that majority of respondents had possession of Cable TV, followed by television and newspaper and had high mass media exposure. Majority of respondents had high utilization of localite sources and low utilization of cosmopolite sources. It was also found that majority of respondents had exposure of PayTm for using cashless system, followed by credit card and internet banking.

\section{References}

Brid, S., Agrahari, K, and Chandran, P. 2017. Study of mobile banking application usage in various sectors of society. International Journal of Scientific \& Engineering Research, 8(5): 33-36.

National Readership Studies Council. 2006. 
"The National Readership Study," Manuscript, New Delhi, India: 48-51.

Tawade, P.H. 2017. "Future and Scope of Cashless Economy in India", International Journal of Advance Research and Innovative Ideas in
Education, 2(3):177-181.

Thomas, B. 2003. "What the World's Poor Watch on TV," World Press Review, 50.https://www.tandfonline.com/doi/full $/ 10.1080 / 00220388.2014 .931939 ? \mathrm{src}=\mathrm{r}$ ecsys.

\section{How to cite this article:}

Manisha Ohlan and Ella Rani. 2019. Communication Pattern for Attaining Information Regarding Cashless System. Int.J.Curr.Microbiol.App.Sci. 8(06): 2718-2724.

doi: https://doi.org/10.20546/ijcmas.2019.806.326 